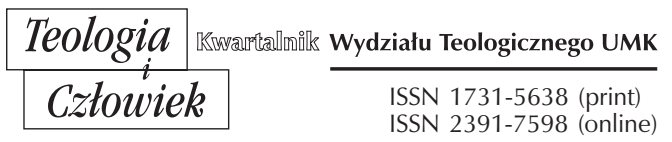

(ब) $\odot \odot$

51(2020)3, ss. $63-80$

KS. KRZYSZTOF MĘTLEWICZ

\title{
SAKRAMENTALNY WYMIAR ŻYCIA CHRZEŚCIJAŃSKIEGO W TEOLOGII JOSEPHA RATZINGERA
}

DOI: http://dx.doi.org/10.12775/TiCz.2020.039

Streszczenie. We współczesnej teologii sakramentalnej dominuje dostrzeganie sakramentów w ich potrójnym wymiarze: historii zbawienia, chrystologii i eklezjologii. Sakramenty bowiem są rzeczywistością, w której Bóg w historii poprzez znaki spotyka się i jednoczy z człowiekiem. Są one także ustanowione przez Chrystusa, który dając je Kościołowi, pozwala na kontynuację misteriów swojego życia w życiu każdego wierzącego. Są wreszcie depozytem wiary Kościoła, który przez ich celebrowanie, widzi w nich horyzontalny wymiar ewangelizacji i świadczenia o byciu uczniem Chrystusa. Artykuł ukazuje te trzy wymiary jako fundamentalne aspekty sakramentologii Josepha Ratzingera, jednocześnie wskazując jego nowe i polemiczne treści wobec błędów doktrynalnych.

Słowa kluczowe: sakramenty chrześcijańskie; historia zbawienia; Jezus Chrystus; Kościół; Sobór Watykański II.

Abstract. The sacramental dimension of Christian life in Joseph Ratzinger's theology. Modern sacramental theology is dominated by the perception of the sacraments in their triple dimension: salvation history, christology and ecclesiology. The sacraments are a reality in which God in history meets through signs and unites with man. They are also instituted by Christ, who, by giving them to the Church, allows the mysteries of his life to continue in the life of every believer. Finally, they are a deposit of the faith of the Church, which, by celebrating them, sees in them the horizontal dimension of 
evangelization and testimony of being a disciple of Christ. The article shows these three dimensions as the fundamental aspects of Joseph Ratzinger's sacramentology, while pointing to its new and polemical content in the face of doctrinal errors.

Keywords: christian sacraments; salvation history; Jesus Christ; Church; Vatican Council II.

Zgodnie z nauczaniem Kościoła katolickiego, sakramenty stanowią widzialny znak niewidzialnej łaski Bożej. Choć Kościół do tej definicji dochodził przez wieki zmagań z pogaństwem, herezjami, czy schizmami, zachowując istotę rozumienia świętych znaków sprawuje je od początku swojego istnienia ${ }^{1}$. Od zawsze bowiem sakramenty, a zwłaszcza chrzest i Eucharystia konstytuowały Kościół, przekładając się bardzo bezpośrednio na egzystencję Jego członków.

Współczesna tematyka sakramentalna stanowi ważną część refleksji jednego z najwybitniejszych żyjących teologów - Josepha Ratzingera (ur. 1927). W podejmowanej przez siebie refleksji mówi on szczególnie o sakramentalnym wymiarze życia chrześcijańskiego. W istocie rzeczy wymiar ten ma oznaczać, że chrześcijanin, który przyjmuje sakramenty zostaje włączony w historię zbawienia, życie Jezusa i życie Kościoła, a przez to jego egzystencja ma wymiar historiozbawczy, chrystologiczny i eklezjalny. Jest to $\mathrm{z}$ jednej strony widocznie nawiązanie Teologa do nauczania Soboru Watykańskiego II, z drugiej zaś jego własne spojrzenie na katolicką sakramentologię, co współcześnie stanowi istotne dla teologii novum.

Celem artykułu jest zaprezentować ten szczególny teologiczny dwutakt, wykazując jednocześnie, w jaki sposób Joseph Ratzinger rozumie sakramentalny wymiar chrześcijańskiej egzystencji.

\section{HISTORIOZBAWCZY WYMIAR SAKRAMENTÓW}

Współczesna sakramentologia bardzo często odwołuje się do tajemnicy historii zbawienia ${ }^{2}$. Od początków istnienia świata i człowieka,

${ }^{1}$ Szerzej na ten temat: K. Mętlewicz, Sakramenty w historii i nauczaniu Kościoła katolickiego, „Ateneum Kapłańskie” 174 (2019) nr 2, s. 99-108.

2 Por. K. Jeżyna, Sakramentalny charakter życia moralnego, „Roczniki Teologii Moralnej” 57 (2010) nr 2, s. 6. 
które powstały w zamyśle Bożej miłości, Stwórca błogosławi swoje stworzenia, w sposób szczególny czyniąc to wobec ludzi. Jak powie „Katechizm Kościoła Katolickiego, począwszy od Abrahama, Boże błogosławieństwo przenika historię ludzi, która zmierzała ku śmierci, by skierować ją do życia, do jego źródła; przez wiarę "ojca wierzących», który przyjmuje błogosławieństwo, zostaje zapoczątkowana historia zbawienia”3. Bóg niezmiennie zapraszał ludzkość do wspólnoty z sobą, czyniąc to przez widzialne znaki swojej niewidzialnej łaski. Objawiał się patriarchom, uobecniał w wyjątkowych wydarzeniach. Dostrzec w nich można nie tylko działającego Boga, który wychodzi do człowieka z sakramentalną inicjatywą, lecz także pełnego wiary człowieka, który ten znak odczytuje i wkracza w Boże przymierze ${ }^{4}$.

Niezwykle ważny w historii zbawienia jest prowadzony między Bogiem a człowiekiem dialog. To on sprawia, że sakramenty nabierają podwójnego charakteru: z jednej strony stanowią dar Boga dla ludzkości, zaś z drugiej odpowiedź wiary obdarowanego. Tę tajemnicę odkryje i zaprezentuje Sobór Watykański II, mówiąc, że celem sakramentów jako znaków uobecnianych w historii zbawienia ,jest uświęcenie człowieka, budowanie mistycznego Ciała Chrystusa, a wreszcie oddawanie czci Bogu"5. W szczególny sposób ten dialogiczny charakter widać w liturgii Kościoła katolickiego, w której Kościół „zjednoczony ze swoim Panem w Duchu Świętym błogosławi Ojca za Jego dar niewypowiedziany przez adorację, uwielbienie i dziękczynienie" rzeczy zmierza w konsekwencji do tego, by człowiek przez sakramenty uczestniczył w życiu Boga, a On mógł się objawiać w egzystencji przyjmującego ${ }^{7}$. W kontekście bosko-ludzkiego dialogu sakramentalnego, Joseph Ratzinger powie, że

3 Katechizm Kościoła Katolickiego (dalej KKK), Poznań 2002, nr 1080.

${ }^{4}$ Por. tamże, nr 1081 - 1083.

${ }^{5}$ Sobór Watykański II, Konstytucja o liturgii świętej Sacrosanctum concilium (dalej KL), w: Sobór Watykański II. Konstytucje. Dekrety. Deklaracje, Poznań 2002, nr 59, s. 63.

6 KKK, nr 1083.

7 Por. B. Nadolski, Słowo Boże i sakramenty święte, w: Katechizm Kościoła Katolickiego. Wprowadzenie, red. M. Rusecki, E. Pudełko, Lublin 1995, s. 151. 
sakrament w swej ogólnej historyczno-religijnej postaci jest przejawem doświadczenia faktu, że Bóg spotyka się z człowiekiem na sposób ludzki, czyli w znakach ludzkiej wspólnoty i w przemianie rzeczywistości wyłącznie biologicznej na rzeczywistość ludzką, która w procesie religijnym przeżywa przemianę w trzeci wymiar, w pewność obecności bytu Bożego w ludzkim ${ }^{8}$.

Człowiek od początku wejścia w historię zbawienia odkrywa, „że rzeczy są czymś więcej niż tylko rzeczami; są znakami, których znaczenie wychodzi daleko poza ich bezpośredni potencjał empiryczny" ". Cała historia zbawienia zmierza do tego, aby człowiek zaczął dostrzegać odwieczną obecność Boga w stworzonym przez Niego świecie. Ratzinger zauważa, że choć ludzkość od zarania dziejów posiadała swoją główną ideę sakramentalności, tak w życiu pozareligijnym, jak i pogańskim, tak chrześcijańskie sakramenty pokazują swoją specyficzną i charakterystyczną zmianę.

Od początków istnienia Kościoła katolickiego, gdy przeanalizuje się jego życie w starożytności, dostrzec można, że sakramenty były rozumiane jako „wydarzenia historyczne, słowa Pisma Świętego, rzeczywistości kultu chrześcijańskiego, którego pozostają w jakiejś relacji do dokonanego przez Jezusa Chrystusa dzieła zbawienia" ${ }^{10}$. Od tej pory, jak dalej powie niemiecki teolog,

Stwórca nie jawi się już jako Bóg Abrahama, Izaaka i Jakuba, a dokładniej jako Bóg Jezusa Chrystusa, jako ten Bóg, który jest dla człowieka i to Jego bycie z nami wchodzi wręcz w Jego definicję. Krótko mówiąc, ukazuje się jako Bóg osobowy, który jest poznaniem i miłością i dlatego jest wobec nas Słowem i Miłością. Słowem, które nas wzywa, i Miłością, która jednoczy nas $\mathrm{z}$ sobą ${ }^{11}$.

Bardzo wyraźnie koresponduje to z nauką Katechizmu, który mówiąc o historii zbawienia w jej punkcie kulminacyjnym umieszcza Misterium Paschalne Chrystusa. Gdy bowiem

${ }^{8}$ J. Ratzinger, Sakramentalne podstawy egzystencji chrześcijańskiej, w: Joseph Ratzinger. Opera Omnia. Teologia liturgii, red. G.L. Müller, pol. red. K. Góźdź, M. Górecka, Lublin 2012, t. 11, s. 191.

\footnotetext{
9 Tamże, s. 190.

10 Tamże, s. 193.

11 Tamże, s. 194.
} 
nadchodzi Jego godzina, przeżywa jedyne wydarzenie w historii, które nie przemija: Jezus umiera, zostaje pogrzebany, zmartwychwstaje i zasiada po prawicy Ojca raz na zawsze. Jest to wydarzenie rzeczywiste, które miało miejsce w naszej historii, ale też jest ono wyjątkowe, ponieważ [...] wydarzenie Krzyża i Zmartwychwstania trwa i pociąga wszystko ku Życiu ${ }^{12}$.

Sakramenty są bowiem uwieńczeniem historii zbawienia, ale przede wszystkim jej kontynuatorami. Przyjmujący je wierni są zatem nie tylko włączeni w odwieczny dialog bosko-ludzki, ale także podejmują osobistą decyzję o kontynuowaniu zbawienia w chronologicznej własnej historii ${ }^{13}$.

Niezwykle ważne dla wskazania wymiaru historiozbawczego w sakramentach przez Ratzingera jest ukazanie ukrytej w nich perspektywy eschatologicznej. Jego zdaniem,

w sakramencie obecna jest historia w całej jej rozciągłości: jako przeszłość, teraźniejszość i przyszłość. Jako „memoria”, powinien docierać do korzeni historii i całej ludzkości, w ten sposób spotykać człowieka w jego teraźniejszości i dawać mu „praesens”- obecność zbawienia, którego istota polega na otwieraniu przyszłości po śmierci ${ }^{14}$.

Każdy wierzący ma tu i teraz doświadczyć spotkania z Bogiem, który dokonał dla niego dzieła odkupienia, aby już dziś go zbawiając, prowadził go w perspektywie dotarcia do stanu wiecznego przebywania z $\mathrm{Nim}^{15}$.

Istotą sakramentów jest włączenie człowieka w rzeczywistość zbawczą. Dlatego, gdy mówi się sakramentach, należy w szczególny sposób zauważyć, że zbawienie przynosi Chrystus Pan, który wszystkie święte znaki ustanowił. To On działa przez nie obecnie, „uobecniając w nich łaskę, którą te sakramenty oznaczają"16.

12 KKK, nr 1085.

13 Por. B. Nadolski, Słowo Boże, s. 151.

${ }^{14} \mathrm{~J}$. Ratzinger, O pojęciu sakramentu, w: Joseph Ratzinger. Opera Omnia. Teologia liturgii, red. G.L. Müller, pol. red. K. Góźdź, M. Górecka, Lublin 2016, t. 11, s. 218.

15 Por. E. Bianchi, Celebrowanie pomiędzy „juz" a „jeszcze nie”. Chrześcijanie świadkami wieczności wśród ludzi, w: Celebracja Ewangelii. Spotkanie z tajemnica Eucharystii, red. E. Bianchi, G. Boselli, tłum. K. Młotek, Kraków 2020, s. 214.

16 KKK, nr 1084. 
Znów, w nawiązaniu do oficjalnej wykładni sakramentalnej Kościoła, J. Ratzinger zauważy, że „jedynym sensem sakramentów jest włączenie człowieka w kontekst historyczny pochodzący od Jezusa"17. Wszystko, co człowiek odkrywał w całej historii przed wcieleniem Chrystusa zmierza głównie do tego, aby wreszcie wejść w dialog z Panem i Zbawicielem ${ }^{18}$. Dlatego, jak dalej zauważy Teolog,

przyjmować sakramenty chrześcijańskie znaczy włączyć się $\mathrm{w}$ historię wywodzącą się od Chrystusa, z wiarą, że jest to ta ocalająca historia, która otwiera przed człowiekiem ów dający mu autentyczne życie kontekst historyczny i doprowadza go do jego autentycznej tożsamości, czyli do jedności z Bogiem - jedności będącej jego wieczną przyszłościąą

Niezwykle ciekawe jest przywołanie przez Ratzingera aspektu tzw. „tożsamości sakramentalnej”. Na czym ona ma polegać? W jaki sposób ją można odkryć? Sakramentalna tożsamość chrześcijanina wyraża się przez swój wertykalny wymiar, wskazując na „wezwanie Boga, czyniące go dopiero prawdziwie człowiekiem"20. W ludzkiej historii, która zdaje się wikłać człowieka w nieuchronność jego przewinień, sakramenty „wprowadzają go w historyczny kontekst z owym Człowiekiem, który był jednocześnie Bogiem” ${ }^{21}$, a przez to stają się „nosicielami historycznego sensu i władzy duchowej, a w konsekwencji - rzeczywistymi mocami zbawczymi i zadatkiem przyszłej chwały"22.

Bóg przez sakramentalny dialog z człowiekiem włącza go w wertykalny wymiar wieczności, jednak w praktyce - to zbawcze spotkanie - oddziałuje na historię człowieka horyzontalnie. Sprawia bowiem, że zostaje on wyzwolony z niewoli grzechu i niemocy, uzyskując Bożą łaskę i zbawienie. Widać zatem bardzo wyraźnie, jak bardzo niemiecki teolog dostrzega i prezentuje historiozbawczy wymiar sakramentów. Z jednej strony Bóg wkracza w historię stworzonych przez siebie ludzi przez dia-

17 J. Ratzinger, Sakramentalne podstawy, s. 196.

18 Por. B. Migut, Znaki Misterium Chrystusa, Lublin 1996, s. 53.

19 J. Ratzinger, Sakramentalne podstawy, s. 196.

20 Tamże, s. 196-197.

21 Tamże, s. 197.

22 Tamże. 
log pełen miłości. Z drugiej zaś przez sakramenty działają niezmiennie „ex opere operato, czyli mocą zbawczą dzieła Chrystusa, dokonanego raz na zawsze"23. Tym samym, ponieważ przez nie działa Chrystus Pan, stają się konieczne do zbawienia ${ }^{24}$. To człowiek jednak decyduje się w ten sakramentalny dialog wejść, by swoją ludzką historię włączyć w historię zbawienia wiecznego i przez to „w żywy sposób zjednoczyć się ze Zbawicielem"25.

\section{CHRYSTOLOGICZNY WYMIAR SAKRAMENTÓW}

Oczywistym jest, że sakramenty Kościoła katolickiego posiadają wymiar chrystologiczny. Jako znaki „ustanowione przez Chrystusa i powierzone Kościołowi ${ }^{26}$ są jednocześnie czynnościami Chrystusa i Kościoła”27. Tę podstawową prawdę o identyfikowaniu się Chrystusa z sakramentami chrześcijańskimi powtórzy Sobór Watykański II ucząc, że „Chrystus jest zawsze obecny w swoim Kościele, szczególnie w czynnościach liturgicznych tak, że gdy ktoś chrzci, sam Chrystus chrzci”28. Nieco dalej dodaje jasno, że „słusznie przeto uważa się liturgię za wykonywanie kapłańskiego urzędu Jezusa Chrystusa"29. Chrystus zatem ustanowił sakramenty, przekazał je Kościołowi i dla Kościoła; objawia przez nie siebie, ale przede wszystkim także sam ich udziela. Tym właśnie sposobem sakramenty są czynnościami najświętszymi, a „żadna inna czynność Kościoła nie dorównuje im skuteczności z tego samego tytułu i w tym samym stopniu"30.

Już od początku gromadzenia się Kościoła na sprawowanie sakramentów, szczególnie chrztu i Eucharystii, w celebracji świętych znaków

\footnotetext{
${ }^{23} \mathrm{KKK}, \mathrm{nr} 1128$.

${ }^{24}$ Tamże, nr 1129.

25 Tamże.

${ }^{26}$ Kodeks Prawa Kanonicznego (dalej KPK), Poznań 2008, kan. 840; KKK, nr 1114.

27 KKK, nr 1114.

${ }^{28} \mathrm{KL}, \mathrm{nr} 7$.

29 Tamże.

30 Tamże.
} 
wspólnota doświadczała, że „dokonują je słowa Chrystusa” ${ }^{31}$. Były one sprawowane z Jego nakazu i w Jego mocy. Od Niego brały początek i do Niego prowadziły przez wiarę $e^{32}$ Katechizm wyraźnie przypomina, że działanie sakramentów w Kościele od Jego początków dokonuje się przez kapłaństwo urzędowe. To właśnie ono zapewnia, że prawdziwie i realnie „W sakramentach działa Chrystus przez Ducha Świętego dla Kościoła”33. Każdy ważnie wyświęcony prezbiter „stanowi więź sakramentalną, która łączy czynność liturgiczną z tym, co powiedzieli i uczynili Apostołowie, a przez nich z tym, co powiedział i uczynił Chrystus - źródło i fundament sakramentów"34. Nie znaczy to jednak, jakoby prezbiter sam udzielał sakramentów, ale nimi szafuje w duchu Kościoła, czyniąc to, co poleca czynić mu w liturgii Chrystus Pan $^{35}$.

Dość powiedzieć, że powyższą wykładnię Katechizmu osobiście redagował i opracowywał Joseph Ratzinger ${ }^{36}$. Warto jednak wskazać na refleksję niemieckiego teologa wokół bezdyskusyjnego powiazania sakramentów z osobą Jezusa Chrystusa. Jak udało się powyżej wykazać, Chrystus Pan przychodząc na świat w kulminacyjnym punkcie historii zbawienia, przez dokonanie Misterium Paschalnego dopełnił i objawił w pełni ekonomię sakramentalną ${ }^{37}$. Sakramenty chrześcijańskie, jak przypomni J. Ratzinger,

nie oznaczają tylko włączenia w kosmos pełen Boga [...] one wskazują na włączenie w historię wywodzącą się od Chrystusa. To stanowi wręcz specyficzne chrześcijańskie przeobrażenie idei sakramentalności. Ono

${ }^{31}$ Ambroży z Mediolanu, Sakramenty, IV, 4, 14, w: Pisma Ojców Kościoła, tłum. L. Gładyszewski, Poznań 1970, t. 26, s. 74.

${ }^{32}$ Por. Historia dogmatów. Znaki zbawienia, red. B. Sesboüe, tłum. P. Rak, Kraków 2001, s. 24-25.

${ }^{33} \mathrm{KKK}$, nr 1120.

34 Tamże.

${ }^{35}$ Por. KPK, kan. 840-841.

${ }^{36}$ W 1986 r. zleciłem Komisji złożonej z dwunastu kardynałów i biskupów z kard. Josephem Ratzingerem na czele przygotowanie projektu katechizmu, o jaki prosili Ojcowie Synodalni - Jan Paweł II, Konstytucja apostolska Fidei depositum, w: Katechizm Kościoła Katolickiego, Poznań 2002, s.12.

37 Por. P.J. Rosato, Wprowadzenie do posoborowej teologii sakramentów, tłum. A. Baron, Kraków 1998, s. 40-41. 
dopiero symbolice naturalnej daje moc zobowiązującą [...] i niezawodną pewność bliskości jednego prawdziwego Boga ${ }^{38}$.

Sakramenty wynikają z historii zbawienia tj. misteriów życia Zbawiciela. Na sposób sakramentalny wierny zanurza się w Jego wydarzenia zbawcze, doświadczając szczególnego z Nim zjednoczenia. Sprawując sakramenty Chrystusa, jak przypomni niemiecki teolog,

człowiek nie wyobraża sobie naiwnie, że wszechobecny Bóg przebywa wyłącznie w tym określonym miejscu, na które w kościele wskazuje tabernakulum [...] Gdy ktoś przychodzi do kościoła i przyjmuje sakramenty to - jeśli wszystko rozumie należycie - czyni to, ponieważ wie, że on jako człowiek może spotkać Boga tylko na ludzki sposób: w relacjach międzyludzkich, w cielesności, w historyczności. Czyni to także w przekonaniu, że jako człowiek nie może decydować, kiedy, gdzie i jak Bóg ma mu się pokazać, że jest raczej istotą przyjmującą, zdaną na całkowitą władzę, której sam nie może sobie udzielićc ${ }^{39}$.

Doświadczenie obecności Chrystusa w sakramentach jest oczywiste, jednak nie jedyne i nie ograniczone przez nie. Jest to niezwykle ważna prawda, którą stale trzeba przypominać szczególnie tym, którzy wierząc niezaprzeczalnie w obecność Chrystusa w sakramentach, nie chcą, lub nie potrafią zauważyć jej w całej działalności Kościoła, a nawet poza nim.

W innym miejscu, mówiąc o związku Chrystusa i liturgii w Kościele, Teolog naucza, że „dokonujące się w sakramentach, w kulcie Kościoła, obdarzanie łaską jest nie tylko udzielaniem przedmiotowych skutków łaski, lecz realnym wchodzeniem w Osobę Chrystusa, które realizuje się w ten sposób, że Jego sakramentach uobecnianie są Jego zbawcze czyny” ${ }^{40}$. Na szczególną uwagę zasługuje wyakcentowanie Jego sakramentów i „Jego czynów zbawczych", które dokonują się w i przez Jego Kościół. Bardzo wyraźnie widać w tym tekście powiązanie refleksji $\mathrm{z}$ oficjalnym Magisterium, gdzie Ratzinger przypomina, że sakramenty są „kontynuacją

38 J. Ratzinger, Sakramentalne podstawy, s. 196.

39 Tamże, s. 200.

40 Tenże, Kościót i liturgia, w: Joseph Ratzinger. Opera Omnia. Kościót - znak wśród narodów, red. G.L. Müller, pol. red. K. Góźdź, M. Górecka, Lublin 2013, t. 8/1, s. 151. 
życia Chrystusa tym samym rzeczywistym centrum chrześcijaństwa"41. Wolą Chrystusa dla Kościoła jest sprawowanie w Nim sakramentów, które „stanowią jedno misterium oraz są misteriami kultu Kościoła, a wszystkie razem misteria kultu stanowią jedną liturgię" ${ }^{2}$.

Pewnym novum w określeniu istoty sakramentów chrześcijańskich, jest powiązanie historycznego wymiaru świętych znaków z wymiarem chrystologicznym oraz eklezjalnym. Zdaniem Ratzingera „historycznym podmiotem chrześcijaństwa jest mistyczne Ciało Chrystusa - Kościół. Jak kiedyś ciało Chrystusa było historycznym podmiotem misterium Chrystusa i Jego ukrzyżowania, tak samo teraz Jego Ciało mistyczne jest historycznym podmiotem urzeczywistniania misteriów w kulcie"43. Co to oznacza dla każdej konkretnej egzystencji chrześcijanina? Liturgia sakramentalna wiążę go z całym Kościołem, który przedłużając historię zbawienia łączy go z Panem oraz wszystkimi swoimi członkami. To z kolei oznacza, że „gdy kapłan w samotności odmawia brewiarz albo najmniejsza nawet wspólnota gromadzi się na Eucharystii, tam jest naprawdę cały Kościół, który - niewidziany - razem z nimi się modli, składa ofiarę i kocha”. Doświadczenie jedności sakramentalnej w Ciele mistycznym Chrystusa jest ciągle trwającym dziełem Zbawiciela, które sprawia, że sakramenty nie należąc do człowieka, są dla niego ustanowione i jemu służą ${ }^{44}$.

\section{EKLEZJALNY WYMIAR SAKRAMENTÓW}

Konstytucja o liturgii świętej Soboru Watykańskiego II naucza, iż w sakramentach „Chrystus zawsze przyłącza do siebie Kościół, swoją Oblubienicę umiłowaną, która wzywa swego Pana i przez Niego oddaje cześć Ojcu wiecznemu" ${ }^{45}$. Sakramenty, ustanowione przez Chrystusa jako celebracja misteriów Jego życia i wydarzeń paschalnych zostały złożone w depozycie wspólnocie Apostołów i uczniów. Ci z kolei pod natchnieniem Ducha Świętego odczytywali „stopniowo ten skarb otrzymany od

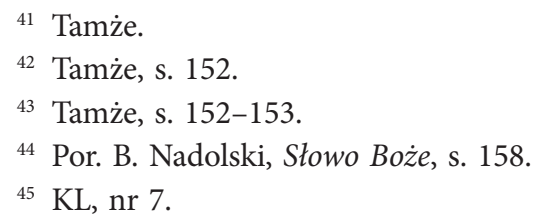


Chrystusa i dokładnie określili sposób „udzielania” go, podobnie jak to czynili w odniesieniu do kanonu Pisma świętego i nauki wiary jako wierni „Szafarze” misteriów Bożych”46.

Z tych dwóch tekstów Magisterium wynikają dwie eklezjalne prawdy o sakramentach. Pierwsza, wcześniej już wyjaśniona, uświadamia, że źródłem i fundamentem sakramentów jest Jezus Chrystus, który sam jest Sakramentem ${ }^{47}$. Z drugiej strony Kościół sam jest sakramentalny, co wynika z obecności Chrystusa w Nim jako Jego Głowy. Skoro więc wszystko, co jest w Kościele, a wiec sam Chrystus jak i dane przez Niego święte znaki noszą charakter sakramentalny, należy je postrzegać zawsze komplementarnie, nie zaś oddzielnie, jakoby sakramenty należały do Kościoła, podczas gdy Chrystus przekazując je wspólnocie pozostaje wobec nich bierny ${ }^{48}$.

Chrystus-Sakrament jest źródłem sakramentów i sakramentalności Ludu Bożego, bowiem „Kościół jest w Chrystusie niejako sakramentem, czyli znakiem i narzędziem wewnętrznego zjednoczenia z Bogiem i jedności całego rodzaju ludzkiego" ${ }^{49}$. Jeśli bowiem sakrament $\mathrm{z}$ definicji jest znakiem obecności i miejscem doświadczenia Boga, to w kontekście świętych znaków Kościół katolicki stanowi niejako Prasakrament, czyli przestrzeń całkowicie przenikniętą obecnością Chrystusa, zanim jeszcze skodyfikowano i określono sposób udzielania samych sakramentów.

Zgodnie z nauczaniem Konstytucji dogmatycznej Lumen gentium, wierni otrzymują sakramenty „od Boga za pośrednictwem Kościoła” ${ }^{50}$. Pośredniczenie nie polega jednak tylko na szafowaniu sakramentami, ale także na ustalaniu sposobu ich udzielania oraz na stwierdzeniu, że wśród ,jego obrzędów liturgicznych jest siedem, które są we właściwym sensie sakramentami ustanowionymi przez Chrystusa" ${ }^{\prime 1}$. Ponadto, Kodeks Prawa Kanonicznego stanowi jasno, że „sakramenty są te same dla całego

\footnotetext{
${ }^{46} \mathrm{KKK}, \mathrm{nr} 1117$.

47 Por. B. Nadolski, Słowo Boże, s. 159.

48 Por. B. Migut, Znaki Misterium, s. 53.

49 Sobór Watykański II, Konstytucja dogmatyczna o Kościele Lumen gentium
} (dalej KK), w: Sobór Watykański II. Konstytucje. Dekrety. Deklaracje, Poznań 2002, nr 1, s. 104.
50 Tamże, nr 11.
51 KKK, nr 1117. 
Kościoła i należą do depozytu wiary ${ }^{52}$ oraz, że tylko do najwyższej władzy kościelnej należy zatwierdzanie lub określanie tego, co jest wymagane do ich ważności" ${ }^{33}$. W praktyce oznacza to, że sakramentalny depozyt wiary nie jest dziełem Kościoła, lecz darem pochodzącym od Jego Głowy, stąd jurydyczne ciało Ludu Bożego winno dokładać wszelkich starań, aby sakramenty były znakami powszechnej jedności, a także by były godnie i ważnie sprawowane ${ }^{54}$.

W określaniu istoty sakramentów chrześcijańskich, czemu niemiecki teolog poświęca część swojej teologicznej refleksji, wskazuje on na ścisłe powiązanie sakramentów jako darów z faktem, że tak jak one - Kościół również pochodzi od Chrystusa. „Stąd rozumienie sakramentu zakłada historyczną ciągłość działania Boga i żywą wspólnotę Kościoła, będącego

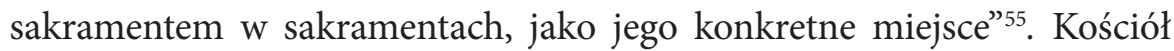
zatem otrzymuje od początków swojej chronologicznej i wertykalnej historii dary sakramentalne, które „są kultowymi czynnościami Kościoła w których działa [...] opierając się na tym, czego sam nie zbudował i w czym daje więcej, niż sam może dać: włącza człowieka w dar, który Kościół sam otrzymuje" ${ }^{26}$.

W tym miejscu niezwykle ważną kwestią jest wskazanie, jaki jest cel udzielania sakramentów w Kościele. Jak stanowi Sacrosanctum concilium, jest nim „uświęcenie człowieka, budowanie mistycznego Ciała Chrystusa, a wreszcie oddawanie czci Bogu" ${ }^{57}$. Z punktu widzenia konkretnej chrześcijańskiej egzystencji, trwając w Kościele przez przyjmowanie sakramentów każdy wierzący ma swój udział w budowaniu Ciała Mistycznego Chrystusa, jednocząc się z Nim, co z kolei dokonuje jego osobistego uświęcenia oraz wzywa do liturgicznego kultu ${ }^{58}$. Dlatego Sobór przypomni, że zanim przystąpi się do sakramentów, Kościół winien zadbać, aby wierzący mogli „rozumieć znaki sakramentalne i gorliwie

52 KPK, kan. 841.

53 Tamże.

${ }^{54}$ Por. tamże, kan. 842-848.

${ }^{55}$ J. Ratzinger, O pojęciu sakramentu, s. 218.

56 Tamże.

57 KL, nr 59.

${ }^{58}$ Por. K. Rahner. Podstawowy wykład wiary, tłum. T. Mieszkowski. Warszawa 1987, s. 344-347. 
przyjmowali te sakramenty, które są ustawione dla podtrzymywania życia chrześcijańskiego" ${ }^{59}$. Skoro jednak uznano, że Kościół stanowi sakrament zbawienia, należy jasno tutaj zaznaczyć, że nie stanowi On celu samego w sobie, ale ze swej natury jest on służebny w kwestii sprawowania sakramentów ${ }^{60}$. Jego zadaniem bowiem jest jednoczenie Boga z ludźmi, nieustanne kierowanie uwagi wierzących na swojego Pana oraz budzenie w ich sercu wiary, którą sakramenty „nie tylko zakładają, lecz za pomocą słów i rzeczy dają jej wzrost, umacniają ją i wyrażają" ${ }^{61}$.

Joseph Ratzinger, mówiąc o związku sakramentów z Kościołem, uświadamia, że jest to „wieź, którą w liturgii sakramentalnej Kościół zacieśnia z Chrystusem, służąc w niej Jemu rzeczywiście za ciało”62. Nieco dalej, konkretyzując tę myśl dopowie: „właśnie w liturgii misteria Chrystusa rzeczywiście stają się obecne w Kościele, że stają się misteriami Kościoła, który w ten sposób staje się ze swej strony ciałem Chrystusa tym, czym jest w swym najgłębszym posłannictwie”63. Teolog próbuje tym samym wskazać na nierozerwalne powiązanie Chrystusa i Kościoła, czego znakiem jest ich związek sakramentalny. Nie można zatem powiedzieć, że sakramenty są tylko Kościoła, lub tylko Chrystusa. Zdecydowanie pełniejszym zdaniem jest stwierdzenie, iż „misterium zbawienia, które było skuteczne w Jego zbawczym czynach, ukazuje On teraz członkom Kościoła"64.

Niemiecki teolog bardzo pozytywnie wypowiada się o potrzebnej reformie obrzędów sakramentalnych, do której wezwała Konstytucja o liturgii świętej. Przed podjęciem tych soborowych postulatów w Kościele obecne było "całkowite uzewnętrznienie zbawienia”65. W czym się to konkretnie przejawiało? „Łaskę i zbawienie pojmowano czysto indywi-

$59 \mathrm{KL}, \mathrm{nr} 59$.

${ }^{60}$ Por. M. Bołoz, Eklezjalne aspekty moralności chrześcijańskiej, Tuchów 1991, s. 101.

${ }^{61} \mathrm{KL}, \mathrm{nr} 59$.

62 J. Ratzinger, Kościół i liturgia, s. 152.

63 Tamże.

64 Tamże.

${ }^{65}$ Tenże, Komentarz - Lumen gentium, w: Joseph Ratzinger. Opera Omnia. O nauczaniu Soboru Watykańskiego II, red. G.L. Müller, pol. red. K. Góźdź, M. Górecka, Lublin 2016, t. 7/2, s. 571. 
dualistycznie, jako ocalenie pojedynczej duszy, której Kościół dostarcza oczywiście urzędowo określone przez Boga środki - sakramenty"66. Słusznie to zjawisko opisuje ks. prof. Krzysztof Konecki, który zauważa, że przed Soborem „liturgia to był przede wszystkim kult oddawany Bogu, zbiór rozbudowanych obrzędów, ceremonii, przepisów, rubryk, nie zaś pogłębiona refleksja teologiczna nad tymi czynnościami, które Kościół wykonuje" ${ }^{67}$. Oczywiście, Kościół jest pośrednikiem sakramentalnym dla wierzących, jednak Sobór w odpowiedzi na taką wizję natury Ludu Bożego, dokonuje głębokiej duchowej refleksji, odkrywa powszechność Kościoła i fakt należenia w pełni do Chrystusa. Jeżeli zatem w kontekście faktu istnienia Kościoła w świecie można wskazać jakiś widoczny dzisiaj sens, J. Ratzinger mówi jasno: „główną formą Kościoła jest zgromadzenie kultyczne"68, a zatem i sprawowanie świętych sakramentów. To jest „właściwy sens i usprawiedliwienie istnienia Kościoła w świecie. Kościół istnieje po to, by wielbić Boga, a skoro największym sensem człowieka jest uwielbienie Boga ustami niemego stworzenia i bycie pomostem pomiędzy nim a Stwórcą, to właśnie w Kościele spełnia się właściwe przeznaczenie samego człowieka"69.

Sakramentologia Vaticanum II pojawiła się także w inny miejscu teologicznej refleksji byłego prefekta Kongregacji Nauki Wiary. Eklezjalny wymiar sakramentów, zdaniem niemieckiego teologa, w sposób szczególny ukazuje sakrament Eucharystii. Sobór słusznie powrócił do eucharystycznego doświadczenia w dziejach Kościoła, dla którego „nauka o Eucharystii i eklezjologia były nierozłącznie ze sobą powiązane. Kościół określał się od Eucharystii i Eucharystia otaczała tajemnicę Kościoła”70. Dalej, chwaląc odnowienie przez Sobór rozumienia sakramentu ołtarza, stwierdza: „Kościół ukazuje się znowu jako tajemnica tych, którzy wspólnie otrzymują Ciało Chrystusa, aby sami stawali się Ciałem Chrystusa, narzędziem

\footnotetext{
66 Tamże.

${ }^{67}$ K. Konecki, Główne założenia teologiczne Konstytucji o liturgii świętej, „Liturgia Sacra” 19 (2013) nr 2, s. 243-244.

${ }^{68}$ J. Ratzinger, Komentarz, s. 573.

${ }^{69}$ Tamże.

${ }^{70}$ Tenże, Kwestie teologiczne na Soborze Watykańskim II, w: Joseph Ratzinger. Opera Omnia. O nauczaniu Soboru Watykańskiego II, red. G.L. Müller, pol. red. K. Góźdź, M. Górecka, Lublin 2016, t. 7/1, s. 290.
} 
bliskości Boga w świecie"71. W teologicznym komentarzu do soborowych postulatów wyłania się niejako apel o komplementarne widzenie Kościoła i Chrystusa w znakach sakramentalnych.

Kościół w szafowanych przez siebie znakach jednoczy się ze swoim Panem. Wymiernym tego skutkiem ma być ciągłe stawanie się Jego poszczególnych członków, tj. wierzących takimi jak ich Zbawiciel. Skoro bowiem w sakramentach dochodzi do intymnego, a zarazem personalnego spotkania Boga z człowiekiem, to poza wewnętrznym uświęceniem konkretnego wierzącego, przyjęty w nim sakrament ma emanować na otaczający go, często zlaicyzowany świat ${ }^{72}$. Jak bowiem, w kontekście przełożenia sakramentów na chrześcijańską egzystencję powie Teolog, „nie ma wyraźnej granicy między liturgią i życiem; liturgia Kościoła zawsze wychodzi poza bramy budynków kościelnych. Kościół żyje kultem, jednak także na odwrót: tam jest kult, gdzie jest liturgia, tam jest też cały Kościół"73. Sakramenty bowiem mogą być przyjęte czysto zewnętrznie, bez osobowego spotkania, a przecież ich skuteczność „zależy od dyspozycji tego, kto je przyjmuje"74.

Tylko pełne zjednoczenie sakramentalne człowieka i trwanie w „tożsamości sakramentalnej” sprawia, że jako członek całego Kościoła buduje Go jako sakrament zbawienia w świecie. Dlatego Ratzinger postuluje niezwykle mocno, by powrócić do istotnego elementu sakramentalnej adoracji i przywrócenia Bogu pierwszego miejsca w czynnościach obrzędowych ${ }^{75}$. Nie boi się więc wprost krytykować tych, którzy posoborowe postulaty o odnowie liturgii sakramentalnej potraktowali błędnie: „interpretując w posoborowych czasach Konstytucję o liturgii świętej, zapominano jednak o tym fundamentalnym prymacie adoracji i traktowano ją wręcz jako liturgiczną recepturę"76.

Przyjmujący sakrament, tj. wierzący zjednoczony z Chrystusem w Jego misteriach, niesienie przez siebie światu łaskę sakramentalną. Nie

71 Tamże.

72 Por. K. Jeżyna, Sakramentalny charakter, s. 9.

${ }^{73}$ J. Ratzinger, Kościót i liturgia, s. 153.

${ }^{74} \mathrm{KKK}$, nr 1128.

75 Por. J. Ratzinger, Pytania o Kościół. Eklezjologia Konstytucji dogmatycznej o Kościele Lumen gentium, „Gość Niedzielny” 27 (2000) nr 1, dodatek „Azymut”, s. 4.

76 Tamże. 
oznacza to jednak, jakoby same sakramenty stanowiły środek ewangelizacyjny, czy opierały się w swej istocie na celowości społecznej. W tym właśnie kontekście Teolog uświadamia, że sakramenty Kościoła „są wyrazem przejrzystości rzeczywistości ludzkiej wskazującej na wymiar Boży”. To z kolei sprawia, że „stanowią one przejaw świadomości, że ludzka społeczność tylko wtedy jest dobrze zakorzeniona, gdy nie opiera się wyłącznie na sobie samej, lecz buduje na tym, co jest od niej większe"77. Kościół jest sobą tylko wtedy, gdy czerpie swoje źródło od Chrystusa-Sakramentu, uświęcając przez pośrednictwo wszystkie swoje członki, co z kolei oddziałuje na pozbawioną korzeni sakramentalnych ludzkość, ukazując się jako wierna Oblubienica Chrystusa i znak sakramentalnego zbawienia wśród narodów.

Sakramentologia Josepha Ratzingera w pełen sposób wpisuje się w oficjalną wykładnię Magisterium Kościoła co do teologicznego wyjaśniania specyfiki świętych znaków. W podjętej przez siebie refleksji wskazuje na trzy istotne wymiary sakramentów, które prezentuje przede wszystkim nauczanie Vaticanum II: historiozbawczy, chrystologiczny i eklezjalny.

Oczywiście, obok dostrzeżenia nawiązań i wyjaśnień posoborowej współczesnej sakramentologii w teologii niemieckiego uczonego, warto zaznaczyć nowatorskie i niespotykane nigdzie indziej teologiczne treści. Do nich należy zwłaszcza wskazanie na tożsamość sakramentalną, którą winien żyć każdy ochrzczony, a która oznacza, że łaska sakramentalna ma mieć wymiar wertykalny i horyzontalny. Teolog wiele miejsca poświęca również ukazaniu, na czym polega unikalność chrześcijańskiego modelu sakramentalnego, który zrywa z czysto kosmologicznym pojmowaniem znaków, włączając wierzącego w misteria życia i śmierci Jezusa Chrystusa. Ponadto podkreśla, że szczególnym zadaniem Kościoła ma być sprawowanie sakramentów, tj. „,jednoczenie ludzi z Chrystusem”, czego szczególnie dziś potrzebuje nie tylko wspólnota Ludu Bożego, lecz także coraz bardziej laicyzujący się świat.

77 J. Ratzinger, Sakramentalne podstawy, s. 192. 
Artykuł zatem dowodzi, że sakramentologia niemieckiego teologa $\mathrm{z}$ jednej strony jasno i wyraźnie koresponduje $\mathrm{z}$ oficjalną wykładnią Kościoła katolickiego, a $\mathrm{z}$ drugiej nie boi się o nowe spojrzenie na sakramenty, którego nie można znaleźć zarówno w reformie obrzędów sakramentalnych, jak i myśli teologów współczesnych.

\section{BIBLIOGRAFIA}

Ambroży z Mediolanu, Sakramenty, IV, 4, 14, w: Pisma Ojców Kościoła, tłum. L. Gładyszewski, Poznań 1970, t. 26.

Bianchi E., Celebrowanie pomiędzy „już a „jeszcze nie”. Chrześcijanie świadkami wieczności wśród ludzi, w: Celebracja Ewangelii. Spotkanie z tajemnica Eucharystii, red.

E. Bianchi, G. Boselli, tłum. K. Młotek, Kraków 2020, s. 211-222.

Bołoz M., Eklezjalne aspekty moralności chrześcijańskiej, Tuchów 1991.

Historia dogmatów. Znaki zbawienia, red. B. Sesboüe, tłum. P. Rak, Kraków 2001.

Jan Paweł II, Konstytucja apostolska Fidei depositum, w: Katechizm Kościoła Katolickiego, Poznań 2002, s. 10-14.

Jeżyna K., Sakramentalny charakter życia moralnego, „Roczniki Teologii Moralnej” 57 (2010) nr 2, s. 5-14.

Katechizm Kościoła Katolickiego, Poznań 2002.

Kodeks Prawa Kanonicznego, Poznań 2008.

Konecki K., Główne założenia teologiczne Konstytucji o liturgii świętej, „Liturgia Sacra” 19 (2013) nr 2, s. 243-251.

Mętlewicz K., Sakramenty w historii i nauczaniu Kościoła katolickiego, „Ateneum Kapłańskie" 174 (2019) nr 2, s. 99 - 108.

Migut B., Znaki Misterium Chrystusa, Lublin 1996.

Nadolski B., Słowo Boże i sakramenty święte, w: Katechizm Kościoła Katolickiego. Wprowadzenie, red. M. Rusecki, E. Pudełko, Lublin 1995.

Rahner K., Podstawowy wykład wiary, tłum. T. Mieszkowski. Warszawa 1987.

Ratzinger J., Komentarz - Lumen gentium, w: Joseph Ratzinger. Opera Omnia. O nauczaniu Soboru Watykańskiego II, red. G.L. Müller, pol. red. K. Góźdź, M. Górecka, Lublin 2016, t. 7/2, s. 569-582.

Ratzinger J., Kościół i liturgia, w: Joseph Ratzinger. Opera Omnia. Kościół - znak wśród narodów, pol. red. G.L. Müller, pol. red. K. Góźdź, M. Górecka, Lublin 2013, t. $8 / 1$, s. $143-162$.

Ratzinger J., Kwestie teologiczne na Soborze Watykańskim II, w: Joseph Ratzinger. Opera Omnia. O nauczaniu Soboru Watykańskiego II, red. G.L. Müller, pol. red. K. Góźdź, M. Górecka, Lublin 2016, t. 7/1, s. 288-300.

Ratzinger J., O pojęciu sakramentu, w: Joseph Ratzinger. Opera Omnia. Teologia liturgii, red. G.L. Müller, pol. red. K. Góźdź, M. Górecka, Lublin 2016, t. 11, s. 202-218. 
Ratzinger J., Pytania o Kościót. Eklezjologia Konstytucji dogmatycznej o Kościele Lumen gentium, Gość Niedzielny 27 (2000) nr 1, dodatek Azymut.

Ratzinger J., Sakramentalne podstawy egzystencji chrześcijańskiej, w: Joseph Ratzinger. Opera Omnia. Teologia liturgii, red. G.L. Müller, pol. red. K. Góźdź, M. Górecka, Lublin 2012, t. 11, s. 185-201.

Rosato P.J., Wprowadzenie do posoborowej teologii sakramentów, tłum. A. Baron, Kraków 1998.

Sobór Watykański II, Konstytucja dogmatyczna o Kościele Lumen gentium, w: Sobór Watykański II. Konstytucje. Dekrety. Deklaracje, Poznań 2002, s. 104-161.

Sobór Watykański II, Konstytucja o liturgii świętej Sacrosanctum concilium, w: Sobór Watykański II. Konstytucje. Dekrety. Deklaracje, Poznań 2002, s. 48-78. 